DOI: $10.1515 /$ ausp-2015-0003

\title{
Ion Valjan: With the Voice of Time. The Hypostasis of a Romanian Belle Epoque
}

\author{
Ştefania Maria CUSTURĂ \\ Sapientia Hungarian University of Transylvania (Miercurea Ciuc, Romania) \\ Department of Humanities \\ stefaniacustura@yahoo.com
}

\begin{abstract}
Ion Valjan is the literary pseudonym of Ion Al. Vasilescu (1881-1960), famous lawyer, playwright, writer of memoirs, publicist and politician. Dramatic author in the line of Caragiale, he was the manager of The National Theatre in Bucharest between 1923 and 1924, and general manager of theatres between 1923 and 1926. He wrote drama, he collaborated with Sburătorul, Vremea, Rampa, being appreciated by the exigent literary critique of the inter-war period. After the war, in 1950, he was involved in a political trial, accused of high treason, espionage for Great Britain, and got sentenced to 15 years imprisonment, where he died. Valjan is the author of the only theatrical show, played in a communist prison, Revista Piteşti 59. Ion Valjan's memoirs, With the Voice of Time. Memories, written during the Second World War, represent a turn back in time, into the age of the author's childhood and adolescence, giving the contemporary reader the chance to travel in time and space, the end of the nineteenth century and the first two decades of the past century projecting an authentic image, in the Romanian version of a Belle Epoque, interesting and extremely prolific for the Romanian cultural life. Also, evoking his childhood years spent in cities by the Danube (Călăraşi, Brăila, Turnu-Severin), Valjan unveils the harmonious meeting of different peoples and their mentalities, which transform the Danube Plain into an interethnic space of unique value.
\end{abstract}

Keywords: Balcanism, identity, alterity, Romanian belle epoque

Ion Al. Vasilescu-literary pen name Valjan-born in 1881, was a lawyer, playwright, memorialist, politician. He studied Law and Philology in Iaşi and obtained his doctorate in Law in Paris. He gained notoriety as a lawyer following the trial Sotiriu-Crețulescu, a famous case in the field of justice. A passionate of theatre, he wrote five comedies that enjoyed the appreciation of the literary critique: What the Village Knew (Ce ştia satul, 1912), The Gordian Knot (Nodul Gordian, 1920), The Tear (Lacrima, 1920), The Sacrifice Generation (Generația de sacrificiu, 1933, 1936), An Inspection (O inspecție, 1941). A collaborator 
of Lovinescu's magazine Sburatorul, of the magazines Rampa and Vremea, he was the manager of the National Theatre in Bucharest (1923-1924), and general manager of theatres (1923-1926). Starting with 1921, he published in magazines pages with a confessional-memorialistic character, on the theme of childhood, of the adolescence that Vasilescu-Valjan spent in the picturesque Balkan towns on the banks of the Danube, Turnu-Severin, Călăraşi, Brăila, where his father, due to his profession (he was a customs administrator) was moved to, every two years. The confessional writings stop at the evoking of the Victory parade in 1918, the author being marked by the arrest of his son Corneliu Valjan by the Soviet secret services (sent to the Gulag from where he would return in 1955). In 1950 Vasilescu-Valjan was arrested, following some ridiculous accusations of espionage in favour of the British powers. He was sentenced to 15 years in jail, he would make "the pilgrimage" of the fiercest communist jails, Aiud, Ocnele Mari and Piteşti, dying at the age of 79 in detention. Even if his dramatic writings would deserve another, more attentive reading, we propose ourselves to take a closer look at his memorialistic work, published by the Humanitas Publishing House under the title of With the Voice of Time. Memories (established text, edition cared for by the author's niece, Micaela Gulea, who also signs the thrilling Epilogue of the volume) in 2013, this being the third edition after those published by the Eminescu Publishing House in 1987 and in 1996.

In the context of contemporary research from imagologic perspectives, Ion Valjan's Memories constitute an ideal and fertile pretext to analyze the relationship between identity and alterity, between the Self and the Other(s), in a space configured by multi-ethnicity in the Danube area (Turnu Severin, Călăraşi, Giurgiu, Brăila) in a topos of differences, eclecticism, of confluences of the European spirit with the Balkan one. The first four chapters are suggestive, from this perspective, 'A long time ago,' 'In Călăraşi,','In Brăila,' 'In Iaşi.' Starting with the fifth chapter, 'Novitiate,' Vasilescu-Valjan's confessions take us into the Bucharest of the 1900s, and the signs of a belle époque with a Romanian perfume become interesting to decipher at the dawn of the process of turning Romanian culture into a southern, Bucharest like culture, a process in which Iaşi, the cultural capital of the elites, loses its supremacy and Bucharest becomes a capital not only from an administrative point of view but mostly from a cultural one. We indulge ourselves in quoting, in this sense, from a savorous work by Dan C. Mihăilescu on the city of Bucharest, his observations finding their full justification in the confessions of Vasilescu-Valjan:

Some find the normality of Bucharest life incredible, absolutely synchronic with the Western Europe of 1900, we being, unfortunately used to the theory of a rude Romania, bordering the desert. (...) we speak of a Romania where the Leu was stronger than the French franc, where, around 1900 
and so, Bucharest was sending help to Paris flooded by the Seine, where on Clementa Street people read Le Figaro with their morning coffee, and letters took a day to any corner of Europe.... (Mihăilescu 2003, 25-26) ${ }^{1}$

We identify another kind of alterity in the chapter entitled 'The War' in Ion Valjan's memorialistic writing. It is his anti-German attitude, but one with strong political connotations, in a country officially Francophone and traditionally Franchophile. Valjan's memoirs render an atmosphere of general rejection of the German expansion politics: "Formidably armed, Germany hurried with a terrifying rush onto Belgium, seeking the road to Paris. Massacres, fires, terror, deportations, destructions, nothing can stop the Teutonic armies on their way to the prey." (Valjan 2013, 317)2 The only one who states his pro-German position, Petre Carp, a member of Junimea, is unanimously condemned, his act being considered "an act of dementia." (idem, 319)

The first chapters of the confessions follow the formation of an identity, of the one confessing in a permanent dialogue with the other, with alterity. The chapter 'A long time ago' is centred on family and school as topoi of formation. The pages dedicated to the school in Ploieşti, where "Mister Maior" used traditional punitive methods, e.g. "would savagely beat the palms with a ruler" (idem, 26), are of an extraordinary verve, similarly to those pages on which the high school Traian from Turnu Severin is evoked, where the method was the same, beating, and an essential component of education was the preoccupation for hygiene. Even though he evokes a Romanian space that stood still in dust and mud, a country that wakes up at the dawn of its modernization, of its becoming European (there were no pavements, no sewer drains, the means of transport were the carriage or the coach, education in schools was done through beating and sending into "detention"), we must remember the profound joy of living, the land of optimism of all, from young to old, the general feeling that the world is beautiful, that life is first of all joy. Reading Valjan's confessions, we understand how healthy the Romanian mentalities of the Beautiful Century were, how happy the people were, and how much the generations to follow retrogressed, ground by wars and crushed by communism. The favourite space of childhood, the village of Cioraca, is the archetype of the Romanian village, with an archetypal figure also, that of the Olt county people. "The Olt people from the north of Olt county are diligent,

1 Quotations from Romanian literature were translated by the author.

2 It would be interesting to bring into discussion the study of professor Lucian Boia, "Germanofilii" - elita intelectuală românească în anii primului război mondial [“Germanophiles.” The Romanian intellectual elite in the years of the First World War] (2009), which undermines the theory that the adepts of the Triple Alliance would have been only small collaborationists, opportunists. To understand the reasons that stand at the basis of the Alliance attitude of most Romanian intellectuals, the chapter 'The War,' the humane but also political, lucid and witty arguments to build a Great Romania must be read. 
overcoming, smart, curious and no work frightens them when it comes to making a living for himself and his family." (idem, 32)

The second chapter announces a change of perspective, the memorialist proposes himself to see what happened "with the then eyes, with the then memories" to speak "with the voice of time" (idem, 35). The link between us and the others is a complex system of alterities. We can only define and form ourselves in a social network, only when we project our own desires onto the others and we let ourselves be influenced by the impulses that alterity addresses to us. This interrelatedness is the leading thread of Ion Valjan's confessions. The Balkan universe that he revives on his pages is special not only because of its picturesque charm, but also due to its force with which it shaped characters, acting in a community in which the Romanians peacefully lived together with Bulgarians, Turks, Greeks, Armenians or Jews. Paul Ricoeur's (2001) observation well fits this context according to which identity is "a field of tensions," a complex network with ethical, ethnic or national components. The identity of the individual who lives in the multicolour towns on the banks of the Danube is interculturally coded and is manifested in a certain unique psychological matrix, defined by the contributions of each people, of each ethnicity. The pages where the memorialist describes the sweets with which the street vendors allure children: from "infuriated doughnuts" to a variety of sorts with oriental-exotic names: bigibigi, salip, sacaz, etc., are a novelty. The best coffee maker is an Armenian, the milkman is Bulgarian, and the kid, when punished, fights an imaginary "cataon" (a Greek, n.a). The identity discourse of the memorialist is born grafted on the ethnic component. It is, of course, about the curiosity and openness towards the Other, being seen as Another, a Foreigner, assimilated peacefully every time.

The arrival of young Valjan in Iaşi in July 1900 is noted by fixing the ethnicities of those individuals he comes into contact with. The coach driver of the onehorse coach is a Russian who "gathered his fat in a velvet coat" (Valjan 2013,102) and steals the clients from the poor Jewish coach driver, the "poor and weak competitor." (idem, 102) ${ }^{4}$ The firms of tradesmen: Barasch, Alexidis, Buch, Weiss, Porjes, Smirnof, Ermacov, Pollingher, Kahane seem to overwhelm him by the fact that they are the names of some Foreigners, and when he finally sees the statue of Miron Costin, he remembers the well-known aphorism of the chronicler "The

3 We cannot ignore the resemblance in spirit with "Childhood memories" by Creangă. It is about the same attitude of the diarist in his mature age who evokes his childhood nostalgically, protectively coated in the bed of his natal village's world. Ciocara is the place where he will always return, no matter how far he could be.

4 "I haven't seen a Jewish coach driver in Muntenia or Oltenia so far", wonders the author, obviously alluding to the fact that these were mostly tradesmen. It is also Valjan who later evokes the Jewish exodus, following the economic crisis during Mitiță Sturdza's period. Thousands of Jews go to America, fascinated by the mirage of an Eldorado that promised a better life. Most of them were small craftsmen and tradesmen. 
times are not in man's command, man is under the times' command". Alterity creates discomfort and awkwardness, because, as the author remembers: "I broke the ties with the world of yesterday and I have no ties with the world I am in." (idem, 103)

We have noticed a growing interest of readers in the genres of diaries, memoirs, and confessions from times gone by. It is most certainly about the reader's feeling of curiosity, whom the diary, the memoirs, the confession allow an indiscreet look into the fold of personal life, about which he couldn't have found out otherwise. We also find in them the faithful mirror of times gone by, an authentic and sincere reconstruction of a modus vivendi, a conservation of the truest and cleanest history, without the voluntary and involuntary falsity of historic study, without the coldness and rigidity of scientific texts. The discussed book represents the unfalsified past and must be read as an authentic source of information of a modus vivendi in the most interesting era in our country, which we elegantly and aristocratically call la Belle Epoque.

Settled along "some Turkish Danube," at a reasonable distance, Călăraşi and Brăila seem cut out of different realities. In Călăraşi, in 1894, only three streets "have some pavement on them" (idem, 40); the mud on the lanes reaches the ankles, the mosquitoes spread malaria, and no day passes without a funeral. The Danube, topos that fuels the Balkan picturesque, is in itself a bad news bearer: the scene in which a whole wedding retinue is swallowed by the hungry waters of the river suddenly melting seems cut out of a Russian film. Brăila, in exchange, seems an earthly paradise, a promised land with its heart beating in the area of the harbour:

in the harbour there is devilish movement, a bustle, a buzz and a mixture of faces and colours such as in a fantastic panorama. Sailors from other harbours, English, Germans, Greeks, Turks, Austrians, Hungarians, with a pipe in the mouth and the cap leaning back, cross roads, push each other, bump into our sailors, speak and call in all languages. Amongst them the go-betweens, the tradesmen and the lemonade sellers who call out their merchandise. Somebody must have overturned the Babel Tower and spilt here on the quays a maddened world. (idem, 72)

The strange charm of the city is fueled by the names of the ship owners, turned legends at the Gates of the Orient: Mendel, Embericos, Galiatzatos, and Dreifus. The inhabitants of Brăila voluptuously emerge themselves in a dolce far niente, which places them on this side of the line that separates the West from the Orient: policemen shoot into the air, nobody can leave the pub until Monday morning, cigarettes are lit up with a 20 Lei banknote, the gypsies in the folk music band play continuously, alcohol is consumed by the bottle, and in Totis restaurant one only drinks wines from Chios and Tenedos. Ion Valjan's literature fixes, through 
painting Brăila, an intermediate zone, an urban space of transition that we call, most of the time with a depreciative meaning, Balkan through the confrontation of two antagonistic tendencies. On one side the barbarian Ottoman Byzantine influences, which give the picturesque character of this city, on the other side the shy attempt of the civilized Europe's influences to put down roots at the mouth of the Danube. The Balkan spirit comes alive in the pages of our memorialist and is visible through all the pores of the writing: cosmopolitanism, voluptousity, vitality to self-destruction, passionate loves, and Fanar laziness; in the middle, standing on a throne, lazy and indifferent-the Foreigner.

The motif of the foreigner has imposed itself in the Romanian literature with different degrees of hostility, and Valjan is not totally a stranger to this feeling. With him it is rather about the feeling of superiority of the one who righteously belongs to these places, different from the Others through his origins, his education. Knowing oneself passes through knowing the other, and the finality of this act is becoming conscious of the fact that "others" represent a social group to which "we" do not belong. The axiological plan of Ion Valjan's writing, albeit discreetly interwoven in the anecdote-thread, is however present and cannot be ignored. Sorin Alexandrescu (1998) defined the myth of identity as being born out of placing Romania, through the force of geographical and historical factors, in a space isolated from Latinity, surrounded by countries of Central Europe, Eastern Europe and the Balkans, the Romanian spirituality making efforts to self preserve itself, through exacerbating traditionalist tendencies, but also through perpetuating a permanent feeling of curiosity towards everything that supposes alterity. The history of events in Ion Valjan's memoir, placed under the sign of the pleasure of telling how the world gone by was, is doubled by a history of mentalities and the memory of an ethnographic picturesqueness, marked by a colourful, contrasting multiethnic mixture, the final result being an identity discourse.

The narrative self is being built in parallel with the formation of an existential Balkan archetype. The Balkan picturesqueness is maintained by the specific topoi, i.e. the fair and the harbour, by typologies such as that of the sailor, the tramps that populate the colourful world of harbours, or that of tradesmen, fishermen, and customs officers. The identity of the memorialist is being built by gradually discovering the charm of reading, of the art of the theatre and of classical music. It is interesting to follow how the adolescent living at the edge of the Orient develops in contact with theatre, literature, music and the friendship of some eminent professors. Ion Valjan's discourse is an authentic, unconcealed pleading for the role and importance of education at the beginning of the twentieth century, when Romanian culture, overwhelmed by traditionalist tendencies and a general feeling of passeisme, was taking its first steps towards synchronizing itself with Western European modernity. "Why should this cosmopolitan fair interest me?" the young man asks, having barely arrived from Călăraşi, "I want however to be as far as 
possible from the noise of city burnt by so many riches... I would not exchange a lyric from Eminescu for the whole gold that is amassed in Brăila.” (Valjan 2013, 73) In Călăraşi he discovered the naïve charm of the books with outlaws or of the plays with Nora Marinescu and Ion Livescu ${ }^{5}$ and shortly afterwards it became clear to him that he could not live without theatre. Numerous and substantial are the notes linked to the modeling effects of art, in general, and of theatre in particular. "A great change had occurred in me since I saw, acted in and read plays", the memorialist confesses and from here on his confessions will pursue not only the reconstitution of a Romanian forma mentis, determining for the transition period from the nineteenth to the twentieth century, but they will also become a diary of intellectual formation, a diary of developing through literature, art and friendships of modeling values, out of which we could name the friendship with writer Panait Cerna, from Ion Valjan's period spent in Brăila. The Danube spirit is favorable for reading, thus the two of them walk the boulevards in Brăila and ardently discuss Goethe, Schiller, Lenau or Schopenahuer.

Extremely interesting are the pages about the two great cultural cities of the time, Iaşi, the cradle of the elitist movement of Junimea, and Bucharest. The former gradually loses its importance, the latter becoming the pulsating heart of the country, through the slow but steady process of turning Romanian culture into a Muntenia style culture. The University of Iaşi, imposing as a temple, the place of accomplishment for the greatest Romanian intellectuals of the time, becomes the space of shaping student Ion Valjan, a student in Law and Philology and at The Dramatic Art Conservatory. In evoking the professors, famous doctrinaires and lawyers, he is respectful and full of gratitude: Tanoviceanu, Dimitrie Alexandrescu, Matei Cantacuzin, Vasile Dimitriu or Constantin Stere. The portrait Ion Valjan makes of Matei Cantacuzin, a descendant of an old boyar family, is special. This depicts "through mind, book and birth three aristocracies: blood, talent and culture aristocracies." (idem, 108) Valjan-Vasilescu's Iaşi is a Romanian Oxford, with professors emeriti, students dedicated to the world of books, of science, where lectures are held and attended, memorable speeches are delivered, conferences are organized in a general atmosphere of enthusiasm, of the joy of living, of trust in the triumph of intelligence, of human reason. Iaşi lives in a rarefied climate of superior intellectuality; it is the Paradise for those who bow to the god of books. And how could you not feel as an intellectual on the ninth cloud, when you have professors such as A. D. Xenopol, Petre P. Negulescu, Ion Găvănescul, Philippide, Teohari Antonescu, etc. We cannot ignore the sensitivity and the piousness with which Iaşi is evoked: "it is the Iaşi of the Mihaileanu Academy, of Eminescu, of Vasile Alecsandri, Titu Maiorescu, Vasile Conta, Negruzzi, Nicu Gane, of the Junimea society, of Convorbiri Literare... Iaşi delights and beauty.” the adolescent exclaims in the theatre hall (Valjan 2013, 61). 
lives closed in its nobility titles, in the poetry of the past, with a lifestyle of its own, with the carriage of an authentic aristocrat." (idem, 111)

Bucharest becomes the capital in 1859, after the Union of the Romanian Principalities, and a Little Paris, at the gates of the Orient, by assiduously using the French language, a bohemian lifestyle, through the variegated mixture of peoples and imitating, in general, of everything that is life in the Paris along the banks of the Seine. For the majority of the Balkan tradesmen, Paris is too far away and they dedicate themselves to business in this miniature Paris on the banks of the Dâmbovița, rapidly turned European, urban settlement at the gates of the Orient, but perfectly impregnated by the cosmopolitan spirit of the French capital.

The chapter entitled 'Noviciat' in Ion Valjan's memoirs describes the ratio identity-alterity from the perspective of the relationship between the outskirts and the center. The memorialist recognizes that he had a choice, between 1903 and 1904, to stay in Iaşi or to leave for Bucharest. The attraction for Bucharest is stronger, "because it has a wider field of activity, there are many credit houses, various public and private institutions, ministries, firms, a living trade, an industrial, political movement." (idem, 137) Bucharest's charm is irresistible, the capital gives birth to its legends on the move, the Kiseleff road with its vivid traffic, with its en vogue world, with luxurious carriages, driven by white horses and names stirring a lot of rumour such as Lilly Gheorghiadis, Mița Biciclista or Lina Colivia, suggestions of the most scandalous habits of Bucharest a long time ago. The country's capital is situated at the confluence of two worlds, attracted not only through the rhythm of its modernization, but also through the fact that it was a city of pleasure, of voluptuousness and depravation.

The chapter 'The Bar of Time. Politics' is a minute and sincere survey made by a Law specialist, an intellectual of deep thought, of the Romanian political life in the proximity of the First World War. The portraits of the great jurists of the time, Take Ionescu, Toma Stelian, Alexandru Djuvara or of the most brilliant criminal law specialist, Barbu Ştefănescu Delavrancea, are special. Their pleadings attract a vast audience, their brilliant intelligence triggers admiration and envy at the same time, and they embody the greatest living school for future Romanian jurists. Delavrancea is not only a specialist in criminal law, he is a "magician," his pleadings attract to the court room doctors, teachers, journalists, artists; the moment he starts speaking Delavrancea is more than a jurist, he becomes an artist, and his speech turns into a monument.

The pages of political analysis of the time are carefully drawn, especially those dedicated to the relationships between Carol I and the conservative party. Also, there are numerous moments in which Ion Valjan expresses his sincere admiration for the one he considered the most illustrious politician of all times, Ion Brătianu. The scope of analysis gradually expands, and the reflection upon the Romanian political life gains European dimensions. The atrocities of war, 
even the reason that triggered it are explainable in Ion Vasilescu's perspective, through the same cursed Balkan spirit, the only one capable of such troubles. Thus the assassination of the Royal Serbian family (King Alexander of Serbia and Queen Draga Masin), planned by a military conspiracy led by another Serbian, Prince Peter Karagheorghevici, could take place in a Slav barbarian and uncivilized environment, predisposed to violence. And in the spirit of the same shameful mixture of Balkanism-Orientalism, the tragedy turned rapidly and deliberately into street show, the hysteric, shocked and curious crowd had something to talk about, being distracted from what was going to happen in Europe. The artist Vasilescu-Valjan perceives reality as a show, sad indeed, and the succession to the state power as a premeditated and mechanic action, led by an invisible mechanism. "We know it all beforehand, as in a play in which the spectator sees from the beginning what line the action shall take on." (idem, 173) In the show of the political life the role of the other is played by King Carol I., a strong, domineering king, in an unuttered warlike stage with the Conservative party, flattered by the Liberals, led by Mititza Sturdza, a king who in history had as only opponent the politician Ionel Brătianu, the uncontested creator of the Kingdom of Romania. How clear and lucid is the portrait that Ion Valjan draws of this controversial character, who indissolubly linked his destiny to that of the Romanian people. "Carol I remained German, through blood, mentality, conceptions, spirit and soul, and sees Romania's interests only in an ideal agreement with German interests. Romania is a necessary satellite for Germany. Working with all probity for Romania, he works for Germany too. He is linked to his native country with a link that no power in the world could undo. He does not forget that he was a Prussian officer, and that he was part of the noble house of the Junkers." (idem, 180) In other words, no foreign leader could love his adopted country more than the country that gave birth to him and to which he belonged feudally, and the political consequences for the first would be excessive.

In such a political context, Transylvania's situation seems hopeless. The image of alterity, embodied by King Carol, becomes complete when Romania enters the First World War, and provides a rather conflictual vision towards the other, of German origin, but manifesting attachment towards French spirituality. Germany is a giant Teutonic creature, which marches mercilessly against the European civilization, and on the other side there are France and Paris as images of humanism, of civilization, in the spirit of unanimous Francophilia. Not only Germans, but also Germanophiles are sworn enemies. The war is fought not only on the front, but also in Bucharest, in political circles and inside cultural groups. Thus, Junimea member Petre Carp, a convinced Germanophile, followed by Marghiloman or C. Arion, becomes the target of indignation of most Romanian intellectuals. The open anti-German attitude brings about the memorialist's arrest (hospitalization) at the Imperial Hotel, and then a deportation in the camp of 
Săveni, in Ialomița county. Săveni becomes for a short period of time the capital of Romanian culture, occupied by the most prestigious Romanian intellectuals of the time-Virgil Dărăscu, doctor Alexandru Obregia, Ionică Pillat, Galction Cordun, C. Rădulescu-Motru and many others-united by the same national ideal, unifying Transylvania with the country and the hatred against the Germans. The memorialist's feelings towards the Germans cover a whole range, from hatred towards a nation considered barbarian, grim and savage, through pity and compassion, forgiveness and human understanding for the trifling German soldier, to finally reach the conclusion that the entire race suffers "a sort of madness" that turns them into merciless conquerors, with an unhealthy drive for destruction. Romania is also devastated by the lack of food, because the Germans take everything to feed their numerous armies. The hatred against them accentuates together with the growing cowardice and of unconditional surrender of the Romanian intellectuals. The memorialist is disgusted by the accepted slavery, by the cowardice, but also by the indifference and platitude of most. And the portrait of feld-marshal Makensen, the conqueror of Romania, above the desk of an eminent jurist in the Palace of Justice leaves him speechless. In such a context, the Allies' victory in 1918 becomes the victory of humanism against barbarians, a frantic moment, a moment of re-awakening the feeling of the joy to live, to call yourself a human being.

Thus, With the Voice of Time. Memories must necessarily be read today, in a climate of globalization and reunification in a great European family. Ion Vasilescu-Valjan's lesson is as follows: a strong person is the one that does not humiliate itself, does not bow to anybody, to which education is primordial, in which the temple is the University, and the dictatorship is one of intelligence and common sense. How few Romanians have learnt this lesson!

\section{Works cited}

Alexandrescu, Sorin. 1998. Paradoxul român. [The Romanian Paradox.] Bucharest: Univers.

Boia, Lucian. 2009. "Germanofilii” - elita intelectuală românească în anii primului război mondial. ["Germanophiles." The Romanian intellectual elite in the years of the First World War.]

Mihăilescu, C. Dan. 2003. Bucureşti. Carte de bucăți. [Bucharest. Book of Bits and Pieces.] Bucharest: Editura Fundației Pro.

Ricoeur, Paul. 1990. Soi-même comme un autre. apud. Andreea Deciu. 2001. Nostalgiile identității. [The Nostalgia of Identity.] Cluj-Napoca: Dacia.

Valjan, Ion. 2013. Cu glasul timpului. Amintiri. [With the Voice of Time. Memories.] Bucharest: Humanitas. 